\title{
Performative Writing as Tool for Social Change
}

\author{
Sara Smits Keeney ${ }^{1}$
}

Writing is vehicle for communicating thoughts and ideas, however it can also maintain the status quo. Traditional ways of writing only recognizes those most privileged in society leaving others marginalized. Using the theoretical texts of other scholars, this paper argues that performative and other alternative styles of writing opens the door to different perspectives. Although performative writing can be challenging for both the writer and the reader, it may be a step towards giving recognition to voices often unheard and ignored. [Article copies available for a fee from The Transformative Studies Institute. E-mail address: journal@transformativestudies.org Website: http://www.transformativestudies.org (C2014 by The Transformative Studies Institute. All rights reserved.]

KEYWORDS: Performative Writing, Postmodern, Social Change, Alternative Writing.

According to the Critical Art Ensemble, in our society (a pancapitalist society), "the education system and the media have become the dominant institutions of socialization" (14). If this is the case, and I believe it is, it is important to look to these institutions to see what it takes to 'succeed' and whether or not this 'success' can be challenged. I would argue that the single most important thing in both these institutions is the ability to communicate or use language 'effectively'. More specifically, education emphasizes the need to write in a way that prescribes to certain established norms. The media reinforces these norms in their hiring practices and in deciding what is fit to print or televise, ultimately

\footnotetext{
${ }^{1}$ Sara Smits Keeney, Ph.D., is an Assistant Professor of Sociology at Saint Anselm College in Manchester, New Hampshire. She earned her Ph.D. at the Maxwell School of Citizenship and Public Affairs at Syracuse University. Her research interests include social movements, militarism, community-based research, and peace and war studies, with a particular interest in the social consequences of war in post-war Vietnam. She is currently working on a community based research project that addresses the bedbug problem locally. Address correspondence to: Sara Smits Keeney, Department of Sociology, Saint Anselm College, 100 Saint Anselm Drive \#1614, Manchester, New Hampshire 03102; e-mail: ssmits@anselm.edu.
} 